\title{
Severe paediatric inflammatory multisystem syndrome temporally associated with SARS-CoV-2 in a 13-year-old boy - case report
}

\author{
Ciężki przebieg PIMS u 13-letniego chłopca - opis przypadku
}

${ }^{1}$ Intensive Care Unit, Jan Bogdanowicz Children's Hospital, Warsaw, Poland

${ }^{2}$ Department of Paediatrics, Jan Bogdanowicz Children's Hospital, Warsaw, Poland

Correspondence: Paweł Jurszewicz, Intensive Care Unit, Jan Bogdanowicz Children's Hospital, Niekłańska 4/24, 03-924Warsaw, Poland, tel.: +48 22509 83 77, e-mail: p.jurszewicz@gmail.com

Abstract Paediatric inflammatory multisystem syndrome temporally associated with SARS-CoV-2 (PIMS-TS) is a recently detected syndrome whose criteria were first established in May 2020 (Royal College of Paediatrics and Child Health). The clinical course varies from mild to severe, life-threatening cases. This paper presents a case of an extremely severe course of PIMS with symptoms resembling Kawasaki syndrome in a previously healthy 13 -year-old boy with obesity. A complication of the severe course of PIMS was the development of critical illness polyneuropathy in the patient.

Keywords: multisystem inflammatory syndrome, PIMS, COVID-19, paediatric population

Streszczenie Dziecięcy wieloukładowy zespół zapalny związany z zakażeniem koronawirusem SARS-CoV-2 (paediatric inflammatory multisystem syndrome, PIMS) to niedawno wykryty zespół chorobowy, którego kryteria ustalono po raz pierwszy w maju 2020 roku (Royal College of Paediatrics and Child Health). Przebieg choroby bywa różny - od przypadków łagodnych do ciężkich, zagrażających życiu. Niniejsza praca przedstawia przypadek skrajnie ciężkiego przebiegu PIMS z objawami podobnymi do zespołu Kawasakiego u 13-letniego chłopca z otyłością, poza tym dotychczas zdrowego. Powikłaniem ciężkiego przebiegu PIMS była ostra polineuropatia stanu krytycznego.

Słowa kluczowe: wieloukładowa choroba zapalna, PIMS, COVID-19, populacja pediatryczna 


\section{INTRODUCTION}

$\mathrm{P}$ IMS, or paediatric inflammatory multisystem syndrome associated with acute infectious disease caused by infection with SARS-CoV-2 virus (severe acute respiratory syndrome coronavirus 2) - COVID-19 (coronavirus disease 2019), is a new entity which affects only the paediatric population. In such case, this complication is secondary to infection with SARS-CoV-2 virus. The American literature mentions PIMS as multisystem inflammatory syndrome in children (MIS-C) ${ }^{(1,2)}$, but the knowledge and experience associated with this entity are so far limited.

The first clearly recorded descriptions or instance on PIMS appeared in Polish and global literature in May 2020 , but they were isolated cases. The first definitions of the disease were presented by the U.S. Centers for Disease Control and Prevention (CDC) and the World Health Organization (WHO) in mid-May 2020. Since October 2020, we have witnessed a significantly higher incidence among the paediatric population in Poland. The disease is now thought to be associated with disorders of the immune system; it develops approximately $2-5$ weeks after passing COVID-19 $9^{(3,4)}$.

While the course of COVID-19 in the paediatric population has so far been scanty or asymptomatic, PIMS always requires hospitalisation, and often treatment at the intensive care unit $(\mathrm{ICU})^{(3)}$. Paediatric mortality ranges from $1-1.5 \%{ }^{(3,5)}$.

Unfortunately, in recent months we have been alarmed to note that more young patients are passing COVID-19 like adults. There are more severe courses with pneumonia, extensive pulmonary lesions, and respiratory failure. Most probably, the main reason for this is the newly detected mutation of SARS-CoV-2, variant B.1.1.7 (the so-called British variant).

A group of experts at the Polish Paediatric Society and the National Consultant in the field of paediatrics has recently established guidelines for the diagnosis and management of children presenting with PIMS symptoms ${ }^{(4)}$.

In line with these recommendations, diagnosis is based on 6 criteria:

1. Age: PIMS affects children (0-18 years of age), and the median age of patients is 8.3 years.

2. Persistent fever $>38.5^{\circ} \mathrm{C}$ that lasts $>3$ days.

3. High levels of inflammatory markers - C-reactive protein (CRP), procalcitonin, interleukin 6 (IL-6), fibrinogen, $\mathrm{D}$-dimer and ferritin, which usually take very high values; the predominant feature is severe lymphopenia, which may facilitate diagnosis.

4. Multiple organ injury:

- Digestive tract: gastrointestinal symptoms, except fever, are the most common and often predominant in patients with PIMS. Symptoms include severe abdominal pain (to differentiate from acute appendicitis), signs of the socalled acute abdomen, vomiting, diarrhoea, peritoneal fluid, features of inflammation of the small and/or large intestine $^{(4,6)}$.

- Cardiovascular and coagulation systems: hypotension, shock, myocarditis, coronary aneurysms, pericardial fluid, arrhythmias, thrombotic complications. Damage to the cardiac muscle with heart failure, reduced ejection fraction, and fractional shortening (FS) are characteristic and significant for the course of disease. With early diagnosis and treatment, the latter does not cause major complications ${ }^{(4,6)}$.

- Nervous system: weakness, apathy, irritability. Approximately $30 \%$ of patients develop symptoms from the nervous system suggesting meningitis (usually aseptic), paresis, and severe headaches ${ }^{(4,6)}$.

- Respiratory system: cough, shortness of breath, pneumonia, pleural fluid or chest pain. The paediatric population may also experience bilateral pneumonia and respiratory failure $^{(4,6)}$.

- Cutaneous and mucosal changes: rash, conjunctivitis, strawberry tongue, dry, red lips, swollen hands and feet $^{(4,6)}$.

5. Exclusion of other causes that may be responsible for the patient's symptoms, including Kawasaki disease, bacterial or viral infections, appendicitis and peritonitis, connective tissue diseases, cancer or inflammatory bowel disease. At present it seems that Kawasaki disease has the most similar course to PIMS, but the latter does not have to fulfil its criteria ${ }^{(4,6)}$.

6. Link to COVID-19. The patient must meet one of the following conditions (at present or in the past):

- positive PCR (polymerase chain reaction) test result or SARS-CoV-2 antigen test;

- positive test for SARS-CoV-2 antibodies;

- documented significant exposure to COVID-19 in the previous 4-8 weeks.

If the patient meets all of the above criteria except No. 6, and there is a strong suspicion of PIMS, especially in a moderately ill child, then we take into account the high frequency of asymptomatic PIMS in children and consider criterion No. 6 as optional.

Treatment of PIMS patients is based on the implementation of immunosuppressive/immunomodulatory therapy, which starts with intravenous immune globulin (IVIg) at a dose of $2 \mathrm{~g} / \mathrm{kg}$ body weight in a 12-hour infusion or in divided doses. From the beginning of treatment, we also use acetylsalicylic acid (ASA) at a dose with antiplatelet activity $(3-5 \mathrm{mg} / \mathrm{kg}$ body weight, max. $75 \mathrm{mg} /$ day). The second treatment of choice are glucocorticosteroids, most often methylprednisolone at a dose $2 \times 1 \mathrm{mg} / \mathrm{kg}$ body weight. The third option are biological medications (anakinra, tocilizumab, infliximab) ${ }^{(7,8)}$.

The presented case report of a 13-year-old boy with PIMS demonstrates the possible severe course of this disease entity and the significance of early diagnosis and implementation of a targeted, immunomodulatory therapy which could lead to significant improvement and recovery. 


\section{CASE REPORT}

A 13-year-old boy with obesity - body mass index, BMI $>99^{\text {th }}$ percentile), otherwise healthy, vaccinated according to the vaccination schedule, was admitted to Jan Bogdanowicz Children's Hospital in Warsaw on 9 November 2020 due to symptoms persisting since 7 November 2020: fever of $40^{\circ} \mathrm{C}$, severe abdominal pain and reduced exercise tolerance.

On 10 October, the boy was in close contact with his grandfather, who on the following day had a high fever with symptoms of upper respiratory tract infection, with negative tests towards infection with SARS-CoV-2. A week later, the boy had subfebrile temperatures up to $37.5^{\circ} \mathrm{C}$ and features of upper respiratory tract infection which subsided the following day. After subsequent 7 days (24 October), the subfebrile temperatures up to $37.7^{\circ} \mathrm{C}$ recurred, with additional headache, malaise, fatigue and reduced exercise tolerance. On 31 October the patient had additional symptoms: stomach ache and nausea, with intensified reduced exercise tolerance. After a week (7 November) the patient developed hectic fever $\left(38.5-40^{\circ} \mathrm{C}\right)$ which responded well to ibuprofen and paracetamol. The child was referred to the hospital by a primary care physician.

Two days later after admission to hospital, the patient was in average general condition. Based on several surgical consultations performed during the patient's stay at the Department of Paediatrics, acute appendicitis was excluded.

SARS-CoV-2 smear test and stool cultures for intestinal viruses and bacteria (Yersinia enterocolitica, Salmonella, Shigella, norovirus) performed on admission were negative. The patient was tested for the presence of infectious factors such as: influenza virus, herpes simplex virus, parvovirus B19, Epstein-Barr virus (EBV), cytomegalovirus (CMV), human herpes virus 6 , with a negative result. Antibiotic therapy with sulfamethoxazole and trimethoprim (p.o.) was started (one dose - day 1 of hospitalisation), and followed by ceftriaxone (days 2-4 of hospitalisation) and vancomycin (days 3-20 of hospitalisation). In the evening of hospitalisation day 3 , the patient's condition worsened significantly. There was intensifying dry cough and weakness, shortness of breath, tachypnoea, leftsided chest pain and paint in upper left abdomen. The patient was administered oxygen via a face mask. The chest radiograph revealed pneumonia (Fig. 1). Due to intensifying respiratory failure, there was a need for an anaesthesia consultation during evening hours. The patient was admitted to the Intensive Care Unit on 11 November (day 3 of hospitalisation).

Diagnostics was expanded with computer tomography (CT) of the chest (Fig. 2). The above-mentioned CT revealed pneumonia, mostly left-sided ("Massive parenchyma density covering almost the entire left lower lung. Similar lesions present in segment 10 of the right lung. Less intense, fine-spotted and ground-glass opacities in the upper lobe

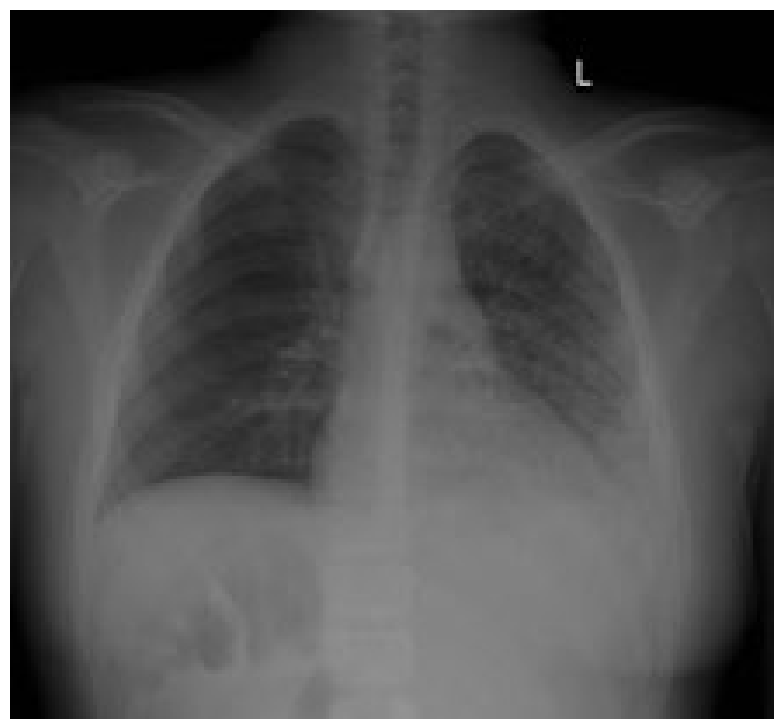

Fig. 1. The chest radiograph on admission to ICU

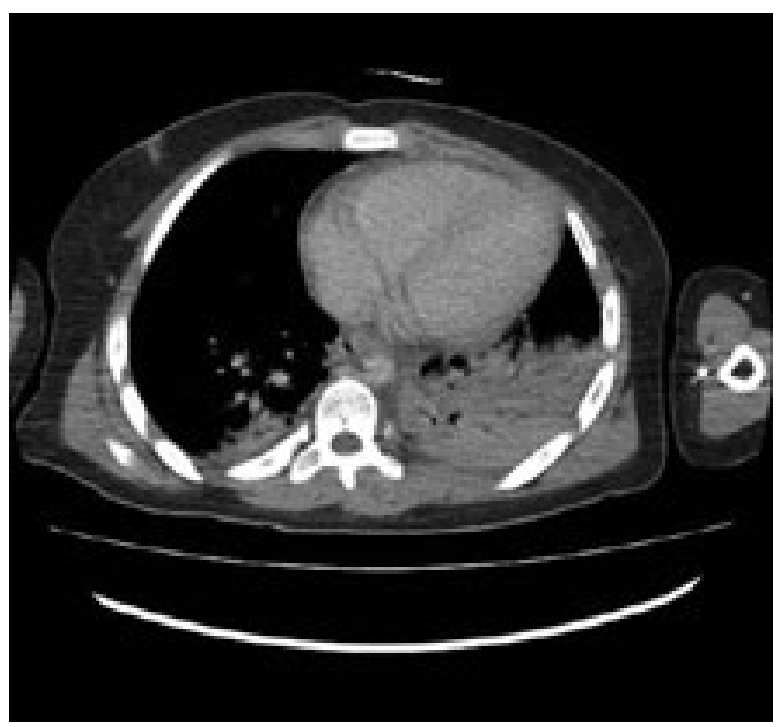

Fig. 2. CT of the chest on admission to ICU, visible left lobe inflammation

of the left lung and in segments 6 and 9 of the right lung [...]. Poor amount of fluid in pelvis, up to about $30 \mathrm{~mm}$. Increased density of pericaecal adipose tissue and at the ascending colon - lesions are probably inflammatory. Spleen enlarged, length $138 \mathrm{~mm}$. Numerous mesenteric and paraaortic lymph nodes, up to about $20 \times 14 \mathrm{~mm}$. Otherwise no lesions on examination of the chest and abdominal cavity"). During the $1^{\text {st }}$ day at the ICU, the patient was conscious with full verbal response, but drowsy. He required oxygen therapy through an oxygen mask [ $4-8 \mathrm{~L} / \mathrm{min}$ (fraction of inspired oxygen, $\left.\mathrm{FiO}_{2} \approx 0.5\right)$ ]. Due to intensifying dyspnoea, the patient required a half-seated position and repeated nebulisation with bronchodilators. In the morning, the breathing pattern improved, the degree of oxygen saturation $\left(\mathrm{SpO}_{2}\right)$ increased from $80 \%$ to $95 \%$, and the respiratory rate was still high - approx. 30 minutes. 


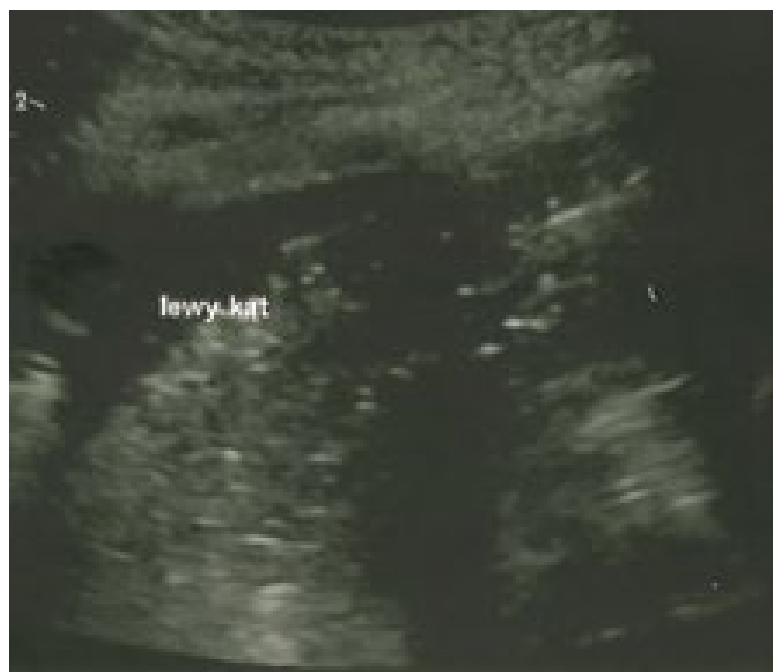

Fig. 3. Lung US on day 2 of admission to ICU, atelectaticlesion - lower lobe of the left lung, peri-diaphragmatic

In the morning hours of 12 November (day 4 of hospitalisation), the patient was conscious, drowsy, and reported chest pain. Breathing was spontaneous, with oxygen therapy of $5 \mathrm{~L} / \mathrm{min}$ (face mask), $\mathrm{SpO}_{2}$ was $98 \%$, without oxygen there were drops to $85 \%$. The boy was at the upper limit of cardiovascular performance, heart rate was $130-140 / \mathrm{min}$, and blood pressure $80 / 50 \mathrm{~mm} \mathrm{Hg}$. He was diagnosed with sepsis and suspected with pneumonia in the course of SARS-CoV-2 infection and paediatric inflammatory multisystem syndrome possibly related to SARS-CoV-2 infection (PIMS). The patient was started with adequate treatment, another nasopharyngeal swab was collected for the PCR test for SARS-CoV-2 virus (ribonucleic acid - RNA virus was not detected), antibody titres were ordered (the result was obtained only on 17 November - positive IgM > IgG). Ceftriaxone was discontinued, the patient was continued on vancomycin, and imipenem and cilastatin were added. There was an increase in inflammatory parameters (CRP $380 \mathrm{mg} / \mathrm{L}$, procalcitonin $38 \mathrm{ng} / \mathrm{mL}$ ) and a step reduction in the concentration of platelets (from 200 to 85 thousand/ $\mu \mathrm{L}$ ). Attention was drawn to the softening and redness of the lips, conjunctiva, gums and tongue, a fine-spotted rash on the hands and feet, red scrotum without swelling and a fever of $38.5^{\circ} \mathrm{C}$. Radial artery cannulation was implemented. Invasive blood pressure (IBP) was measured, a hemodynamic monitoring platform was connected [calibrated with the cardiac index (CI), and assessed on echocardiography - ECHO]. Superior vena cava cannulation was installed through the right internal jugular vein to treat the progressing hypotension. The boy presented with anxiety syndrome and reported severe pain in the chest and abdomen. Intravenous infusions of chlorpromazine and nalbuphine in fractionated doses every 4 hours were used. Due to hypoxemic respiratory failure increasing in the afternoon and $\mathrm{SpO}_{2}$ drops to $70 \%$ despite oxygen supplementation, we

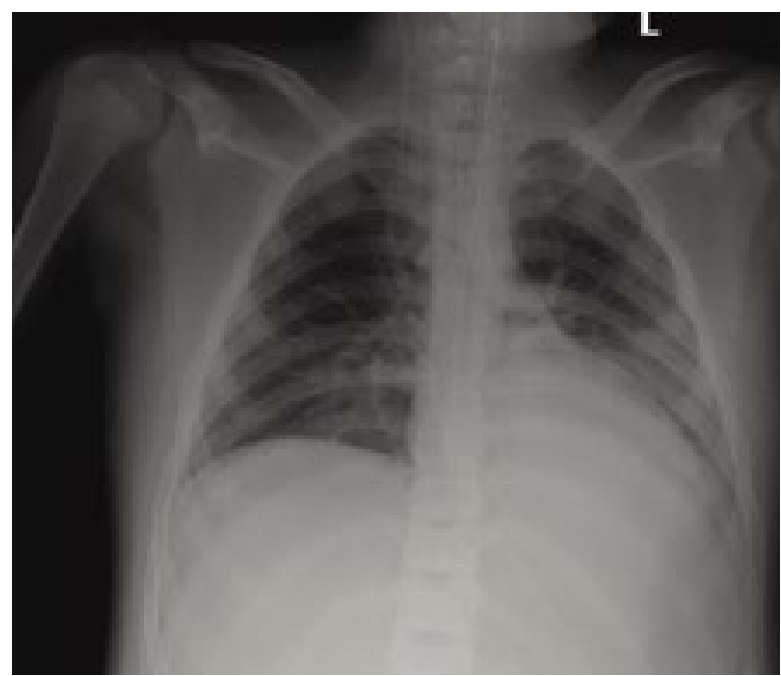

Fig. 4. The chest radiograph on day 2 of treatment at ICU, shortly after intubation

implemented noninvasive ventilatory support with the use of nasal cannula through supply of high-flow oxygen (HFO) - $\mathrm{FiO}_{2}$ 0.7; flow 40-60 L/min with beneficial effect ( 8 hours of treatment) in the form of good oxygen levels and respiratory effort reduction. Lung ultrasound (US) in the BLUE (bedside lung US in emergency) protocol revealed: on the left side, a large atelectatic inflammatory consolidation in the lower lobe projection with an estimated $300 \mathrm{~mL}$ of surrounding fluid in the pleural cavity (Fig. 3), the upper lobe projection was also found with numerous convergent B-lines, with bilateral pleural sliding confirmed. There are numerous B7 lines (6-8 in the visual field of the screen) visible above the entire right lung - an image of interstitial pneumonia. At the base of the right lung there was a slight atelectatic inflammatory consolidation with no fluid (Fig. 4). During the night, there was a further deterioration of respiratory function, increased respiratory effort and changes in the nature of fluctuating consciousness; $\mathrm{SpO}_{2}$ decreased to $75 \%$ (oxygenation index 100). Endotracheal intubation was performed with sedation (fentanyl $2 \mu \mathrm{g} / \mathrm{kg}$, ketamine $1.5 \mathrm{mg} / \mathrm{kg}$, thiopental $3 \mathrm{mg} / \mathrm{kg}$ body weight). The patient was connected to a ventilator in synchronised intermittent mandatory ventilation - pressure control (SIMV PC) + pressure support (PS) - positive end-expiratory pressure (PEEP). Despite $\mathrm{FiO}_{2}$ 1.0, saturation was stable at $60-70 \%$. The patient initially required an hourly recruitment by gradually increasing PEEP from 5 to $17 \mathrm{~cm} \mathrm{H}_{2} \mathrm{O}$. Recruitment manoeuvres significantly improved oxygenation and lung compliance. $\mathrm{SpO}_{2}$ increased from $60 \%$ to $99 \%$, driving pressure $(\Delta \mathrm{P})$ decreased (calculable at bedside as plateau pressure minus positive endexpiratory pressure) from 20 to $15 \mathrm{~cm} \mathrm{H}_{2} \mathrm{O}$, tidal volume (TV) was $450-520 \mathrm{~mL}, \mathrm{FiO}_{2}$ dropped from 1.0 to 0.5 , PEEP was 14-17 $\mathrm{H}_{2} \mathrm{O}$. Arterial blood gas parameters (partial $\mathrm{O}_{2}$, $\mathrm{pO}_{2}$ ) increased from 56 to $105 \mathrm{~cm} \mathrm{H}_{2} \mathrm{O}$, without $\mathrm{CO}_{2}$ retention. The boy developed cardiorespiratory failure. 
Norepinephrine infusion was administered - initially $0.03 \mu \mathrm{g} / \mathrm{kg}$ body weight $/ \mathrm{min}$ to $0.3 \mu \mathrm{g} / \mathrm{kg}$ body weight $/ \mathrm{min}$. Ultrasound in FATE (focus-assessed transthoracic echocardiography) protocol was performed - cardiovascular US protocol using transoesophageal echocardiographic imaging, which aims to identify pathologies in the cardiovascular system that may be the cause of the patient's life-threatening condition). Cardiac chamber ratio was normal, with no clinically significant regurgitation, no volumetric or pressure overload characteristics, inspiratory collapse of the inferior vena cava was $38 \%$, velocity time integral left ventricular outflow tract (VTI LVOT): 22, LVOT surface area: $3.14 \mathrm{~cm}^{2}$, stroke volume (SV): $69 \mathrm{~mL}$, cardiac output (CO): $7.5 \mathrm{~L} / \mathrm{min}$, fractional shortening (FS): 32\%, stroke volume variation (SVV): $15 \%$. There was a trend towards life-threatening hypotension of $40 / 20 \mathrm{~mm} \mathrm{Hg}$ with a decrease in pulmonary perfusion [carbon dioxide partial pressure $\left(\mathrm{pCO}_{2}\right)$ decreased to $15 \mathrm{~mm} \mathrm{Hg}$ on capnography waveform] and a decrease in the systemic vascular resistance index (SVRI) to 400 dyn $\times \mathrm{s} / \mathrm{cm}^{5} / \mathrm{m}^{2}$, with maintained correct CI. The developed hypotension was associated with vasodilatation secondary to the systemic inflammatory response syndrome (SIRS) and the need for bolus sedation (thiopental $0.5 \mathrm{mg} / \mathrm{kg}$ ) due to periodic agitation during the induction phase. The patient responded well to two fluid boluses of $5 \mathrm{~mL} / \mathrm{kg}$ body weight, Trendelenburg position and norepinephrine bolus. After the second episode of hypotension, we implemented adrenaline infusion $(0.05 \mu \mathrm{g} / \mathrm{kg} / \mathrm{min})$ with beneficial haemodynamic effect [SVRI increase $800-900$ dyn $\times \mathrm{s} / \mathrm{cm}^{5} / \mathrm{m}^{2}$, mean arterial pressure $(\mathrm{MAP}) \approx 70 \mathrm{~mm} \mathrm{Hg}$. There were elevated lactate levels in arterial blood gas (gradually decreasing from 8.0 to $1.5 \mathrm{mmol} / \mathrm{L}$ ), as well as increasing troponin concentration up to a maximum of $834 \mathrm{ng} / \mathrm{L}$. At night, after intubation, the patient was sedated with an intravenous multimodal infusion (thiopental, ketamine, dexmedetomidine, morphine). There were no features of bleeding. Due to the suspicion of PIMS with the Kawasaki-like disease phenotype, the patient was started on antiplatelet therapy (ASA $50 \mathrm{mg} / \mathrm{kg}$ body weight), low molecular weight heparin ( $1 \mathrm{U} / \mathrm{kg}$ body weight/day) and an intravenous 6-hour infusion of immunoglobulins $(2 \mathrm{~g} / \mathrm{kg}$ body weight). Patient hydration included oral (before sedation, water, $20 \%$ glucose, Nutridrink) and intravenous (balanced crystalloids $-60 \mathrm{~mL} / \mathrm{h}$ ) administration. Initially, moderate hypovolemia was observed (SVV 25-35\%). Normovolaemia was achieved gradually (SVV $8-14 \%)$, yet diuresis was poor $(0.5 \mathrm{~mL} / \mathrm{kg}$ body weight/h). Furosemide was used in fractionated doses with beneficial diuretic effect.

On day 3 of ICU treatment, an established initial diagnosis was followed by two telephone cardiology consultations with two leading centres in Warsaw. Based on the experience of these centres and the description of the disease published in "The Lancet" ${ }^{(10)}$, the supply of immunoglobulins

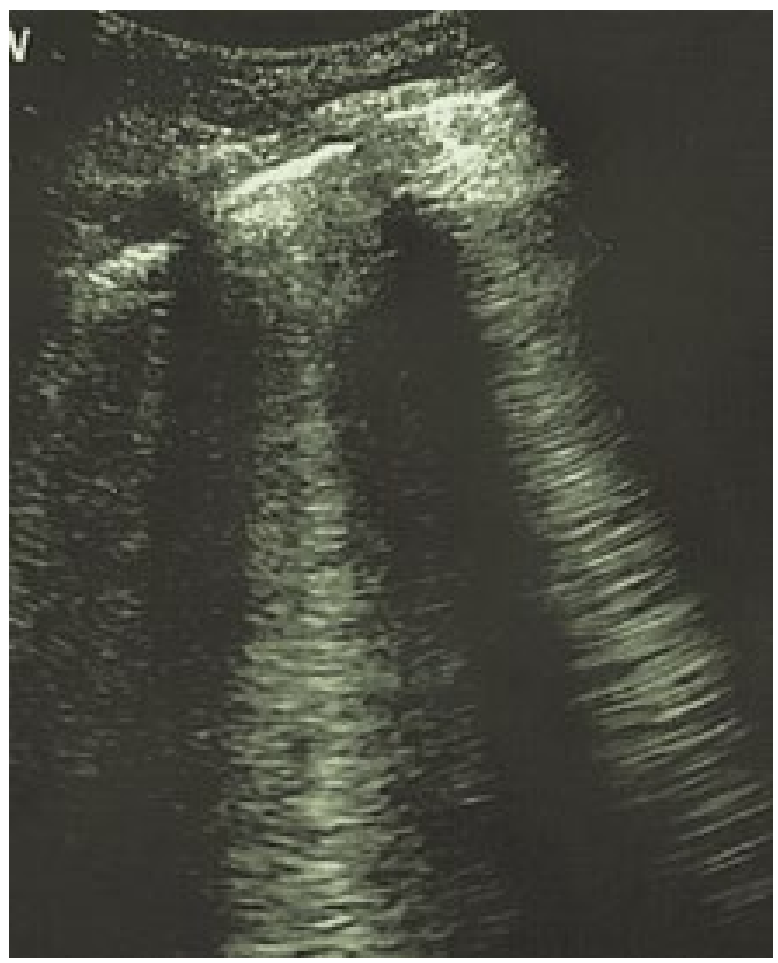

Fig. 5. Lung US on day 3 of ICU treatment, middle lobe of the right lung - visible subpleural consolidations with B lines (alveolar stage of pneumonia)

( $2 \mathrm{~g} / \mathrm{kg}$ ) and ASA at a dose of $50 \mathrm{mg} / \mathrm{kg}$ body weight/day in 4 divided doses was maintained. Antibiotic therapy was modified by adding amikacin and fluconazole in a prophylactic dose and steroid therapy (replacing dexamethasone with methylprednisolone at a dose of $10 \mathrm{mg} / \mathrm{kg}$ body weight). Gastrointestinal bleeding prophylaxis with a proton pump inhibitor was implemented. Due to hypoalbuminaemia, $20 \%$ of albumin was transfused. Despite antipyretic treatment (paracetamol and pyralgin every 6 hours), the temperature did not fall below $39.5^{\circ} \mathrm{C}$. The patient was started on intravenous infusion of chlorpromazine, physical cooling (ice water circulation for inducing therapeutic hypothermia) and iced gastric lavage, which gradually decreased body temperature. Respiratory therapy was continued, ventilation parameters were reduced under the control of gasometry (decrease in PEEP: from 15 to $10 \mathrm{~cm} \mathrm{H}_{2} \mathrm{O}$, $\mathrm{FiO}_{2}$ 0.5; reduced PS: from 16 to $13 \mathrm{~cm} \mathrm{H} \mathrm{H}_{2} \mathrm{O}, \mathrm{SpO}_{2}$ 96-100\%). Follow-up US of the lungs revealed numerous $\mathrm{B}$ lines on both sides - the image of interstitial pneumonia passing into vesicular pneumonia (Fig. 5) and consolidations in the lower lobes of both lungs, without accumulation of pleural fluid. Bronchopulmonary lavage was performed during bronchoscopy, and followed by a culture and a test for SARS-CoV-2, which was negative. Finally, only the positive titre of anti-SARS-CoV-2 antibodies, which were determined on the $7^{\text {th }}$ day of ICU stay, allowed to confirm PIMS. Circulation was supported by infusions of noradrenaline $(0.09 \rightarrow 0.06 \mu \mathrm{g} / \mathrm{kg} / \mathrm{min})$ and adrenaline $(0.04 \mu \mathrm{g} / \mathrm{kg} / \mathrm{min})$, which were discontinued during the day. 
In the following days of ICU stay, the patient's condition gradually improved. Ventilation parameters were reduced, frequent changes in body position, patient positioning on the stomach, patting, and intensive passive rehabilitation were used. From the $3^{\text {rd }}$ day, the patient did not require adrenaline, and from the $5^{\text {th }}$ day noradrenaline.

On day 4 of the ICU stay, lung US performed in the lower lobe of the right lung revealed a large, fresh atelectatic inflammatory consolidation with visible fluid, confirmed by additional X-ray examination, and from day 6 , withdrawal of consolidation changes in the lower lobes of both lungs was observed. On day 8, ECHO revealed the presence of fluid in the pericardial cavity $(5-9 \mathrm{~mm}$ behind the right ventricle, up to $12-18 \mathrm{~mm}$ at the apex of heart without tamponade features) that did not increase in volume and was almost completely absorbed after a few days.

Since intubation, attempts have been made at enteral feeding (Nutrini Energy), including trophic feeding, which turned out to be ineffective due to numerous retention and backup of stomach contents. On day 6 of ICU stay, parenteral nutrition $(1,500 \mathrm{kcal})$ was introduced. The patient required periodic furosemide in order to maintain normal hourly diuresis.

The depth of sedation was gradually reduced - intravenous infusion of ketamine was abandoned (on day 5 of ICU stay), and the speed of intravenous infusions of morphine and thiopental was reduced. From day 5 the fever subsided; therefore, chlorpromazine was discontinued. On day 8 , morphine infusion was stopped, and on day 9 thiopental, and the supply of methadone through the probe began.

On 21 November (day 12 of hospitalisation), the boy woke up from the coma. After a few hours, he was extubated and connected to non-invasive ventilation (face mask). The patient had problems with effective coughing and expectoration of secretion. Periodic pharyngeal aspiration under sedation with propofol was required. Intensive respiratory physical therapy and frequent changes of position were continued, including positioning on the stomach for 6 hours a day. The next day, the patient was able to breathe independently through a face mask with a reservoir and then with a regular oxygen mask. Despite the lack of sedation, contact with the boy was difficult. On 22 November, there was a generalised tonic-clonic seizure with a good response to diazepam.

On 23 November, due to anxiety and periodically recurring pain, analgosedation was started (clonidine infusion $0.1 \mu \mathrm{g} / \mathrm{kg} / \mathrm{h}$ ). The possibility of contact was preserved, the patient was able to comply with instructions, but he did not speak. Patient examination revealed significantly decreased muscle strength, lack of passive and active movements, and reduced tendon reflexes in the limbs. Magnetic resonance imaging of the brain and a neurological con- course of severe multiorgan failure, and the epileptic seizure was associated with withdrawal syndrome. In the following days, the neurological deficits gradually subsided. On 24 November, the boy made verbal contact. However, he showed symptoms of anxiety, and was therefore started on treatment with alprazolam $(4 \times 0.25 \mathrm{mg})$ and propranolol $(2 \times 10 \mathrm{mg})$ and provided with psychological care together with his mother. The patient also received melatonin $(5 \mathrm{mg})$ at night and clonidine (p.o.) $(150 \mu \mathrm{g} /$ day $)$. In the next few days, the therapy was modified. The doses of methadone and clonidine were reduced gradually to a complete stop, and an intravenous infusion of dexmedetomidine $0.6 \mu \mathrm{g} / \mathrm{kg} / \mathrm{h}(1.2 \mu \mathrm{g} / \mathrm{kg} / \mathrm{h}$ at night $)$ was administered. Insomnia was managed with two overnight intravenous infusions of propofol $(3 \mathrm{mg} / \mathrm{kg} / \mathrm{h})$, and the circadian rhythm was restored after a few days. The boy's neurological condition continued to improve gradually.

On 24 November, we introduced intragastric feeding Nutrini Peptisorb in a trophic dose $(3 \times 50 \mathrm{~mL})$ and cisapride (10 mg every 8 hours). Every other day, the caloric supply was increased up to $2,000 \mathrm{kcal}$ (27 November). At the same time, the caloric content of parenteral nutrition was reduced. Water supply was intensified. Supply of intravenous fluids was limited. Peristalsis was normal, the patient was passing stools.

On 28 November (day 17 of ICU stay), we performed laboratory tests which showed a CRP increased to $33 \mathrm{mg} / \mathrm{L}$ (at noon to $50 \mathrm{mg} / \mathrm{L}$, the next morning - $170 \mathrm{mg} / \mathrm{L}$ ). The boy had a fever of $38.7^{\circ} \mathrm{C}$. Central cannula was removed. Cultures were secured (blood, urine, bronchoaspirate, tip of central cannula catheter - negative results were obtained). Hospital-acquired pneumonia was diagnosed and antibiotic therapy was initiated with piperacillin with $4.5 \mathrm{~g}$ tazobactam 4 times a day. The patient was breathing on his own and supplemented with oxygen through the nasal cannula $\left(\mathrm{SpO}_{2} 90-99 \%\right)$. Intensive respiratory physical therapy was continued. There was persistent symmetrical vesicular murmur with numerous crackles over the lung fields. Coughing and expectoration remained unproductive, but tended to improve. During sedation with propofol, secretions from the laryngeal inlet and trachea were aspirated, resulting in copious purulent discharge. Lung US revealed profile A, preserved bilateral sliding, a small number of $B$ lines and a minor consolidation at the base of the left lung (which tended to heal) and massive new consolidation in the middle and lower lobes of the right lung, which was confirmed by chest X-ray (Fig. 6). The patient was cardiovascularly stable (MAP $\approx 75 \mathrm{~mm} \mathrm{Hg}$ ). Heart US performed in the FATE protocol revealed correct proportions of the heart chambers, CO: $7 \mathrm{~L} / \mathrm{min}, \mathrm{SV}: 53 \mathrm{~mL}$, left ventricular measurement parameters normal, FS: $33 \%$, mitral annular plane systolic excursion (MAPSE): $1.2 \mathrm{~cm}$, traces of fluid in the pericardial cavity. Coronary arteries could not be visualised. The administration of low molecular weight heparin at a prophylactic dose and ASA at a dose of $75 \mathrm{mg} /$ day was maintained. 


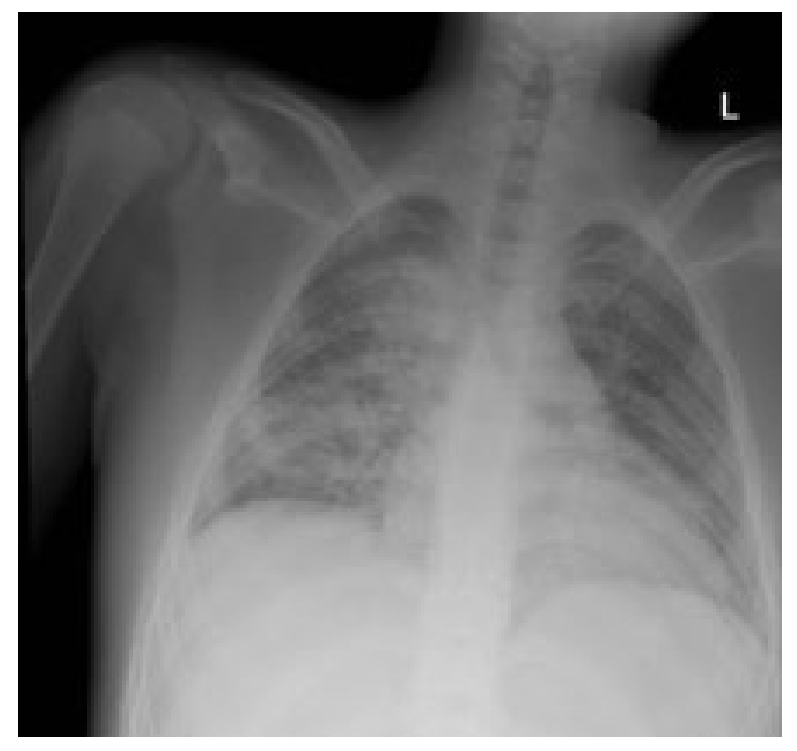

Fig. 6. The chest radiograph on day 17 of hospitalisation

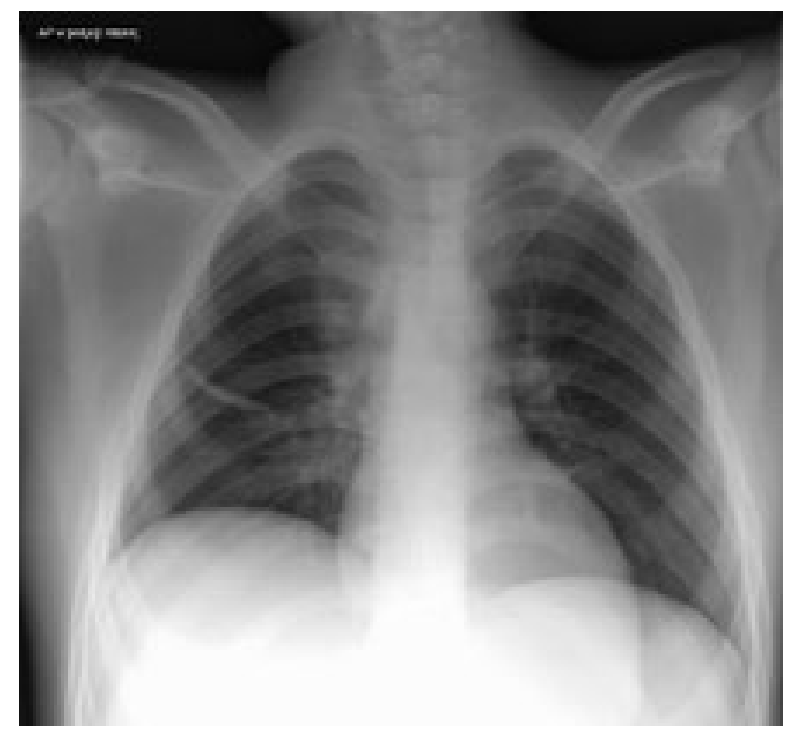

Fig. 7. Lungs on 3 December (day 24 of hospitalisation) Department of Paediatrics

In the following days of stay at the ICU, the patient's clinical condition improved, which was confirmed by a decrease in inflammatory parameters and an improvement in magnetic lung imaging (Fig. 7).

On 30 November, the cardiovascularly and respiratorily stable patient was transferred to the Department of Paediatrics for further treatment, with full logical verbal contact.

\section{DISCUSSION}

The diagnosis of PIMS with Kawasaki-like disease phenotype was indicated both by clinical criteria and the results of diagnostic and imaging tests, which allowed to establish the final diagnosis.

That said, it must be emphasised that the initial course of the disease suggested a multiorgan failure typical of septic shock with an unknown aetiological factor, which required immediate treatment, including the use of broad-spectrum antibiotics. Due to the strong suspicion of PIMS, treatment for this disease was applied simultaneously. Due to the critically severe clinical condition, the patient was started on immunoglobulins and, without waiting for the result, on steroid therapy. However, it was not certain what disease we were dealing with. Only after obtaining negative results of numerous cultures and positive anti-SARS-CoV-2 antibody titres (day 7 of ICU stay) was it possible to establish the final diagnosis.

In the context of the severity of the PIMS syndrome, it is worth noting that the boy, despite the lack of chronic diseases, was obese (BMI $>99^{\text {th }}$ percentile), which undoubtedly seems to be a significant risk factor for complications from SARS-CoV-2 infection ${ }^{(9)}$.

At the same time, the analysis of laboratory test results showed a certain regularity (Fig. 8 and Tab. 1) regarding increases in leukocytosis, repeated regularly with an interval of 4-5 days, without full correlation with increased CRP or fever. However, this requires further research.

In view of numerous scientific reports on the adverse effect of vitamin D deficiency on the severity of the course of SARS-CoV-2 infection, it is also important to pay attention to its significant $(23 \mathrm{ng} / \mathrm{mL}$ ) deficit in the presented case report. There is still a shortage of publications indicating a direct link between this fact and the risk of PIMS in children, but it seems very likely.

It should be emphasised that the severe course of PIMS with acute respiratory distress syndrome (ARDS) and accompanying multiorgan failure syndrome of very rapid course accounted for only about $6 \%$ of cases described in American publications.

\section{CONCLUSIONS}

The initial course of PIMS is mild, but after a few days (on average days 4-5), it can bring deterioration of health, especially if adequate treatment has not been introduced. Some patients develop multiorgan failure. It is extremely important to make a quick diagnosis and undertake relevant medical intervention which could limit the turbulent - in some cases - progress of disease and protect the patient from severe implications. Implementing immunomodulating treatment leads to quick recovery. It must be stressed that PIMS may closely resemble sepsis, but often times it does not respond to standard, broad spectrum antibiotics.

To conclude, in case of increasing generalised features of multiorgan failure in children, we should now take into account the multisystem inflammatory syndrome which is a complication secondary to SARS-CoV-2 infection.

\section{Conflict of interest}

The authors report no financial or personal connections with other persons or organisations that could adversely affect the content of the publication and claim the right to this publication. 


\section{CRP and WBC count}

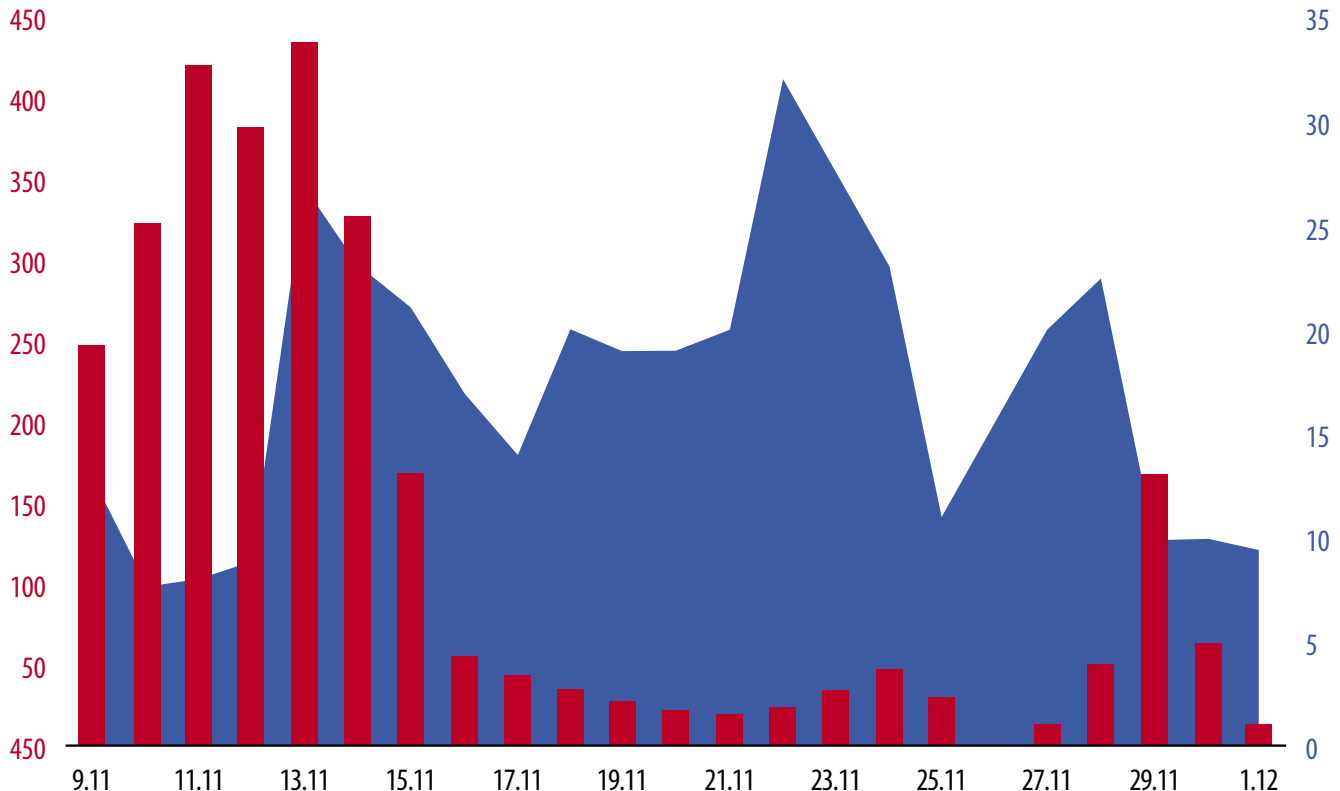

Fig. 8. Graphical presentation of CRP $[\mathrm{mg} / \mathrm{L}]$ and white blood cells $(\mathrm{WBC})[\mathrm{K} / \mu \mathrm{L}]$ during hospitalisation

\begin{tabular}{|c|c|c|c|c|c|c|c|c|c|c|}
\hline Day & $\begin{array}{c}\text { WBC } \\
{[\mathrm{k} / \mu \mathrm{L}]}\end{array}$ & $\begin{array}{c}\text { Neutrophils } \\
\text { [\%] }\end{array}$ & $\begin{array}{c}\text { Lymphocytes } \\
{[\%]}\end{array}$ & $\begin{array}{c}H G B \\
{[g / d L]}\end{array}$ & $\begin{array}{l}\text { HCT } \\
{[\%]}\end{array}$ & $\begin{array}{c}\text { PLT } \\
{[\mathrm{k} / \mu \mathrm{L}]}\end{array}$ & $\begin{array}{c}\text { CRP } \\
{[\mathrm{mg} / \mathrm{L}]}\end{array}$ & $\begin{array}{c}\text { PCT } \\
{[\mathrm{ng} / \mathrm{mL}]}\end{array}$ & $\begin{array}{c}\text { Troponin } \\
\text { [ng/L] }\end{array}$ & $\begin{array}{l}\text { D-dimers } \\
\text { [ng/mL] }\end{array}$ \\
\hline 9.11 & 13 & 85 & 5.7 & 13.8 & 39 & 202 & 245 & & & \\
\hline 10.11 & 7.7 & 89 & 4.3 & 13 & 38 & 139 & 320 & & & \\
\hline 11.11 & 8 & 86 & 6.4 & 12 & 34 & 84 & 418 & 19 & 25 & \\
\hline 12.11 & 9 & $x$ & $x$ & 11 & 32 & 72 & 380 & 38 & 135 & 2,365 \\
\hline 13.11 & 27 & 95 & 2.7 & 11 & 31 & 111 & 433 & 37 & 834 & 1,827 \\
\hline 14.11 & 23 & $x$ & $x$ & 9 & 27 & 113 & 324 & 25 & 436 & \\
\hline 15.11 & 21 & 91 & 5.6 & 10 & 31 & 129 & 167 & 14 & & 1,190 \\
\hline 16.11 & 17 & 88 & 7.8 & 11 & 33 & 163 & 55 & 9 & & \\
\hline 17.11 & 14 & 87 & 7.6 & 11 & 33 & 189 & 43 & 5 & 112 & 882 \\
\hline 18.11 & 20 & 91 & 4 & 11 & 33 & 235 & 33 & 3 & 101 & 840 \\
\hline 19.11 & 19 & 91 & 4 & 10 & 31 & 277 & 27 & 2 & 64 & 717 \\
\hline 20.11 & 19 & 89 & 4.5 & 9 & 28 & 352 & 22 & 1 & 56 & 850 \\
\hline 21.11 & 20 & 91 & 3.3 & 9.2 & 27 & 361 & 19 & 0.6 & & 829 \\
\hline 22.11 & 32 & 91 & 3.3 & 10 & 31 & 541 & 23 & 0.4 & & \\
\hline 23.11 & 27 & 92 & 3.7 & 10 & 31 & 534 & 33 & & & 803 \\
\hline 24.11 & 23 & 91 & 4.9 & 10 & 31 & 589 & 47 & 0.2 & & \\
\hline 25.11 & 11 & 77 & 13 & 9 & 28 & 465 & 30 & 0.12 & & \\
\hline 27.11 & 20 & 81 & 9.3 & 10.8 & 33 & 697 & 13 & 0.09 & & 1,049 \\
\hline 28.11 & 22.5 & 84 & 7.5 & 11.2 & 34 & 613 & 50 & 0.2 & 59 & 1,629 \\
\hline 29.11 & 10 & 68 & 21 & 8.9 & 26 & 378 & 167 & & & 1,162 \\
\hline 30.11 & & & & & & & 62 & 0.18 & & \\
\hline 1.12 & 9.5 & 66 & 20 & 10 & 30 & 391 & 12 & & 8 & 1,782 \\
\hline 9.12 & 5.5 & 45 & 38 & 10 & 30 & 496 & $<5$ & & $<1.5$ & 544 \\
\hline
\end{tabular}

Tab. 1. Selected laboratory figures 


\section{References}

1. Riphagen S, Gomez X, Gonzales-Martinez C et al.: Hyperinflammatory shock in children during COVID-19 pandemic. Lancet 2020; 395: 1607-1608.

2. Royal College of Pediatrics and Child Health: Guidance. Paediatric mulstisystem inflammatory syndrome temporally associated with COVID-19. Available from: https://www.rcpch.ac.uk/ sites/default/files/2020-05/COVID-19-Paediatric-multisystem-\%20inflammatory\%20syndrome-20200501.pdf.

3. Okarska-Napierała M, Ludwikowska KM, Szenborn L et al.; Mois CoR Study Group: Pediatric inflammatory multisystem syndrome (PIMS) did occur in Poland during months with low COVID-19 prevalence, preliminary results of a nationwide register. J Clin Med 2020; 9: 3386.

4. Okarska-Napierała M, Ludwikowska KM, Książyk J et al.: Postępowanie $\mathrm{z}$ dzieckiem $\mathrm{z}$ wieloukładowym zespołem zapalnym powiązanym z COVID-19. Wytyczne Grupy Eksperckiej przy Polskim Towarzystwie Pediatrycznym i Konsultancie Krajowym w dziedzinie pediatrii. Przegl Pediatr 2020; 49: 1-9.

5. Godfred-Cato S, Bryant B, Leung J et al.; California MIS-C Response Team: COVID-19-associated multisystem inflammatory syndrome in children - United States, March-July 2020. MMWR Morb Mortal Wkly Rep 2020; 69: 1074-1080.
6. Whittaker E, Bamford A, Kenny J et al.; PIMS-TS Study Group and EUCLIDS and PERFORM Consortia: Clinical characteristics of 58 children with a pediatric inflammatory multisystem syndrome temporally associated with SARS-CoV-2. JAMA 2020; 324: $259-269$.

7. Harwood R, Allin B, Jones CE et al.; PIMS-TS National Consensus Management Study Group: A national consensus management pathway for paediatric inflammatory multisystem syndrome temporally associated with COVID-19 (PIMS-TS): results of a national Delphi process. Lancet Child Adolesc Health 2021; 5: $133-141$.

8. Henderson LA, Canna SW, Friedman KG et al.: American College of Rheumatology clinical guidance for multisystem inflammatory syndrome in children associated with SARS-CoV-2 and hyperinflammation in pediatric COVID-19: version 1. Arthritis Rheumatol 2020; 72: 1791-1805.

9. Feldstein LR, Rose EB, Horwitz SM et al.; Overcoming COVID-19 Investigators, and the CDC COVID-19 Response Team: Multisystem inflammatory syndrome in U.S. children and adolescents. N Engl J Med 2020; 383: 334-346.

10. Viner RM, Whittaker E: Kawasaki-like disease: emerging complication during the COVID-19 pandemic. Lancet 2020; 395: 1741-1743. 